\title{
PEMANFAATAN WEBSITE BISNIS UNTUK MENINGKATKAN KESEJAHTERAAN UKM DI MAKASSAR
}

\section{UTILITION OF BUSINESS WEBSITE IN ORDER TO INCREASE THE PROPERITY OF UKM IN MAKASSAR}

\author{
Hasnawiya Hasan 1), Haliah Imran ${ }^{2)}$ Alief Fadhal ${ }^{3)}$. \\ ${ }^{1}$ Teknik Sistem Perkapalan,Universitas Hasanuddin \\ ${ }^{2}$ Akuntasi,Universitas Hasanuddin \\ ${ }^{3}$ Teknik Elektro, Universitas Hasanuddin \\ ${ }^{1}$ Email: hasnahasan@unhas.ac.id
}

\begin{abstract}
Abstrak: Jumlah usaha kecil dan menengah (UKM) di kota makassar setiap tahun semakin besar. UKM merupakan salah satu media masyarakat bukan hanya sebagai penopang kehidupan sehari hari tapi juga impian masyarakat untuk berkembang menjadi masyarakat ekonomi atas yang mandiri. Namun, kenyataannya pengelolaan UKM ternyata tidaklah sederhana, masalah dana dan pemasaran produk merupakan problematika terbesar yang dihadapi masyarkat Indonesia pada umumnya. Dalam mendapatkan pelanggan dalam jumlah besar, terkadang masyarkat pengelola UKM membutuhkan lokasi yang stategis. Sementara harga lokasi yang strategis sangatlah mahal. Oleh karena itu, pemanfaatan website bisnis akan sangat membantu UKM UKM kecil yang terletak di lokasi tak strategis. Selain daripada itu, website bisnis juga akan menggambarkan keindahan dan keunikan produk yang dijual. Sehingga, website bisnis yang dirancang untuk UKM Pratama ini, dibangun dengan teknik hand coding dengan menggunakan beberapa bahasa pemograman seperti PHP,CSS,dan javascript. Seiring dengan perubahan perilaku masyarkat masa kini yang telah terbiasa dengan dunia internet dan media sosial, sehingga pengubahan UKM konvensional menjadi UKM digital akan lebih memberi efek yang positif bagi masyarakat masa depan.
\end{abstract}

Kata Kunci: UKM, Websites, PHP, CSS, Javascript

Abstract: The number of small and medium business (UKM) in makassar is increasing every year. UKM is one of the media for the society to fullfill their daily need and also to grow as a society with a high income. However, UKM management is not simple, fund and marketing are the biggest problem that UKM society faced today. Sometimes UKM need a strategist location in order to get a large number of society. While, the price of strategic location is very expensive. Therefore, a bisnis websites will be very helpfull for these UKM which located in bad location. Otherwise, a bisnis website also will adding beautifullness and uniqness to the products. Therefore, a business websites for this Pratama UKM is developed with hand coding technique using some coding languange such as PHP,CSC, and javascript. A long with the change attitude that accure in the society, where they are more likely to use internet and social media for their daily 
INTEGRITAS : Jurnal Pengabdian

Vol 5 No 1 Juli 2021

ISSN $2580-7978$ (cetak) ISSN 2615-0794 (online)

activities.Therefore, transformation from UKM conventional to UK digital will bring more positive impact on the future society.

Keywords: UKM, websites, PHP, CSS, javascript.

\section{PENDAHULUAN}

Makassar merupakan salah satu kota dengan tingkat pembangunan ekonomi yang pesat di Indonesia. Besarnya jumlah pengangguran membuat kota ini sarat dengan persoalan ekonomi dan sosial. UKM merupakan salah satu bentuk usaha rakyat menengah kebawah untuk meningkatkan kesejahteraan mereka. Berbagai macam UKM berkembang di kota ini. Pada umumnya UKM ini dikembangkan oleh ibu-ibu rumah tangga yang ingin membantu usaha suaminya. UKM di kota ini umumnya bergerak dibidang kuliner, sebab masyarakat di kota ini memang terkenal penikmat kuliner terbesar di Indonesia. Berbagai macam usaha kuliner dikembangkan di kota ini. Umumnya kuliner tersebut sangat enak dan disenangi turis manca negara.

Namun ternyata, pengelolaan UKM secara tradisional tak banyak membantu masyarakat kota ini. Banyak UKM UKM kecil itu bangkrut di masa pandemic corona, karena adanya PSBB dan kurangnya masyarakat yang keluar rumah. Adanya jasa pengantaran seperti gojek dan grab juga tak terlalu membantu penjualan usaha mereka. Oleh karena usaha kuliner mereka kurang terkenal, sehingga masyarakat jarang yang memesan kuliner ini. Catering pratama merupakan salah satu UKM yang terkena imbas dari virus korona ini. Walaupun tanpa adanya penyebaran virus korona dan PSBB, usaha kulineran ini juga sulit berkembang, oleh karena kurangnya media promosi bagi usaha ini. Lokasi UKM ini yang terletak di kompleks perumahan jauh dari jalan poros kota, membuat usaha ini kurang berkembang. Sementara, membangun usaha yang terletak di jalan poros kota, tentunya membutuhkan modal yang sangat besar. Masalah seperti ini, bukan hanya dialami oleh UKM Pratama, tapi mayoritas UKM UKM di Indonesia.

Oleh karena itu program pengabdian ini bertujuan untuk membantu UKM ini berkembang di masa pandemic ini dan seterusnya. Program ini bertujuan untuk membantu memasarkan produk kulineran dari UKM Pratama dengan 
INTEGRITAS : Jurnal Pengabdian

Vol 5 No 1 Juli 2021

ISSN 2580-7978 (cetak) ISSN 2615-0794 (online)

memanfaatkan website bisnis. Website bisnis ini akan memperlihatkan produk produk kulineran dari UKM ini, dengan menggunakan teknik photoshop yang menarik dan uraian produk yang menjual, sehingga masyarakat mampu melihat kelebihan dan keunikan dari UKM ini secara meluas. Dengan adanya website bisnis, UKM Pratama tidak lagi membutuhkan tempat berusaha yang startegis dalam meningkatkan penjualannya. Seiiring dengan berubahnya perilaku masyarakat, yang kini lebih banyak menggunakan media sosial dan internet dalam segala aspek kehidupannya. Sebuah website bisnis juga sering merupakan simbol profesionalisme dari pemilik usahanya.

\section{METODE}

Membangun sebuah website bisnis yang professional untuk sebuah UKM, membutuhkan persiapan yang matang. Website ini harus mampu memperlihatkan keindahan dan kelezatan dari produk kuliner yang ditawarkan, agar masyarakat sebagai konsumen tertarik untuk membeli. Oleh karena itu website ini dibangun dengan menggunakan teknik hand coding. Adapun website coding terbagi atas tiga bagian yaitu ;

a. Front end ; yaitu bagian dari website yang mengatur isi dan tampilan dari website, disusun dengan bahasa pemograman antara lain HTML, CSS, dan Java script

b. Back end ; yaitu bagian belakang layar dari websites yang tidak berhubungan langsung dengan user, disusun dengan bahasa pemograman antara lain; phyton, ruby, PHP.

c. Full stack adalah bagian dari websites yang bekerja pada front end dan back end.

Beberapa bahasa pemograman web yang digunakan dalam merancang sebuah web antara lain :

1. HTML (Hypertext Markup Language) merupakan basic bahasa pemograman websites, ditulis dalam format ASCII. Oleh karena itu, pada dasarnya websites adalah sebuah plain text yang telah mengalami encoded oleh HTML sehingga 
terformat baik pada web browser. Developer dapat memasukkan video, gambar,musik, dll (Faithe Wempen, 2011).

2. CSS (Cascading Style Sheet); merupakan program yang membuat tampilan dari HTML agar lebih terstruktur dan menarik, berwarna, dan interaktif. Developer dapat memasukkan video, gambar, dan musik ke dalam website dan menfromatnya menjadi tampilan yang menarik. (Tiffani, 2015)

3. Javascript merupakan bahasa pemograman yang akan membuat websites menjadi lebih menarik, web developer dapat menambah fitur interaktif, seperti memberikan efek, memberikan animasi, dll. (Terry,2010)

4. Phyton adalah bahasa pemograman yang digunakan pada bagian backend developer. Phyton mampu berjalan di berbagai sistem operasi. (Tim Hall and JP Stacey, 2009)

Website yang dibangun untuk UKM Pratama adalah website tipe bisnis dengan menggunakan Bahasa pemograman untuk web coding antara lain PHP,CSS, dan javascript.

\section{HASIL DAN PEMBAHASAN}

Hasil dan luaran yang diperoleh dari program pengabdian ini berupa website bisnis yang dibuat khusus untuk memasarkan UKM Pratama. Dengan adanya webste ini, UKM Pratama semakin meningkat dan telah mampu memperkerjakan sekitar sepuluh orang pegawai. UKM Pratama telah memiliki mitra mulai dari kalangan pabrik besar, instansi pemerintah, hingga masyarakat yang hendak mengadakan hajatan. Website ini mampu mengangkat nama UKM kecil seperti catering Pratama menjadi UKM yang terlihat professional di kalangan maysarakat sekitar. Beberapa, tampilan website dari UKM Pratama adalah sebagai berikut: 


\section{INTEGRITAS : Jurnal Pengabdian}

Vol 5 No 1 Juli 2021

ISSN 2580-7978 (cetak) ISSN 2615-0794 (online)

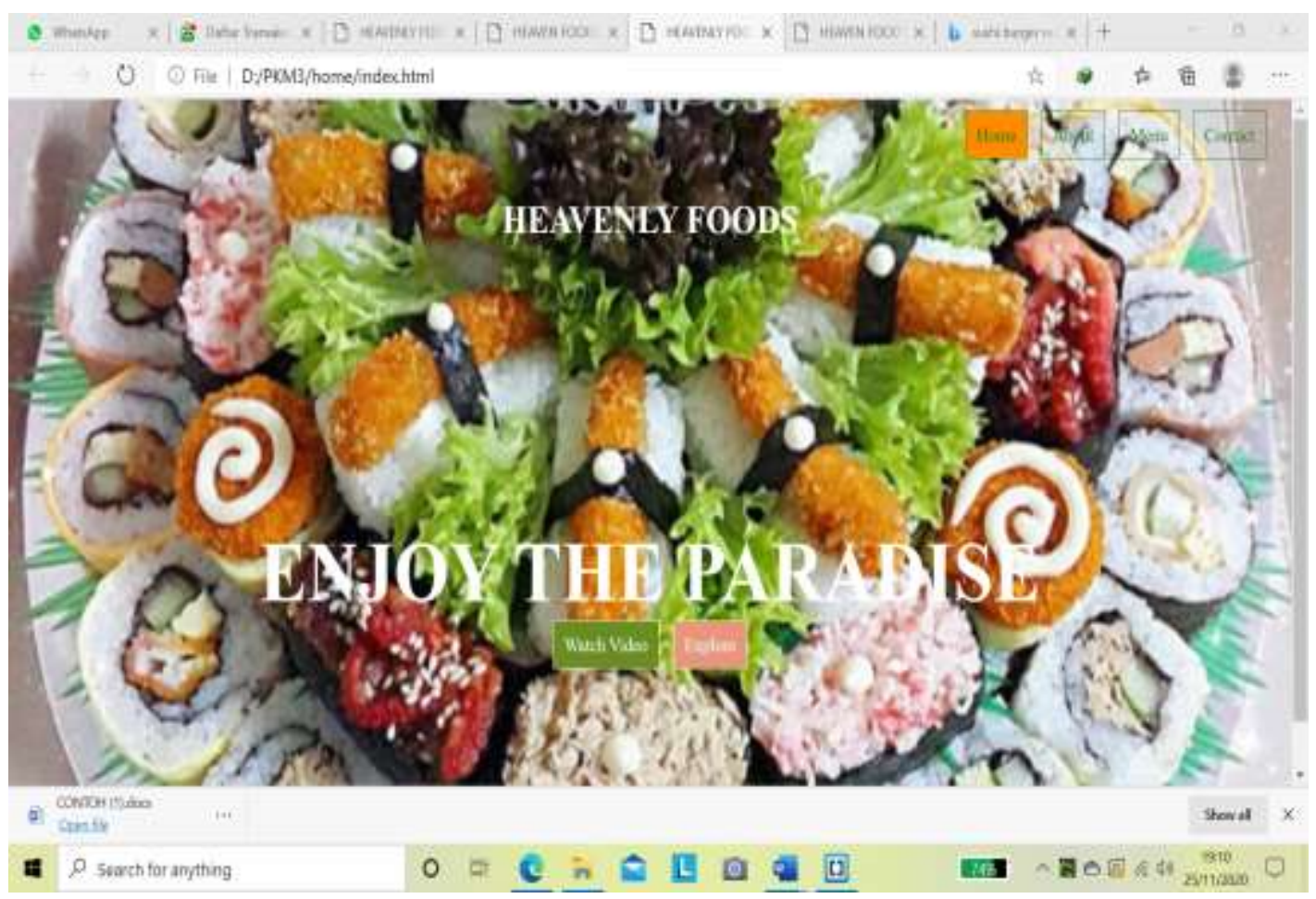

Gambar 1. Tampilan lay out depan websites

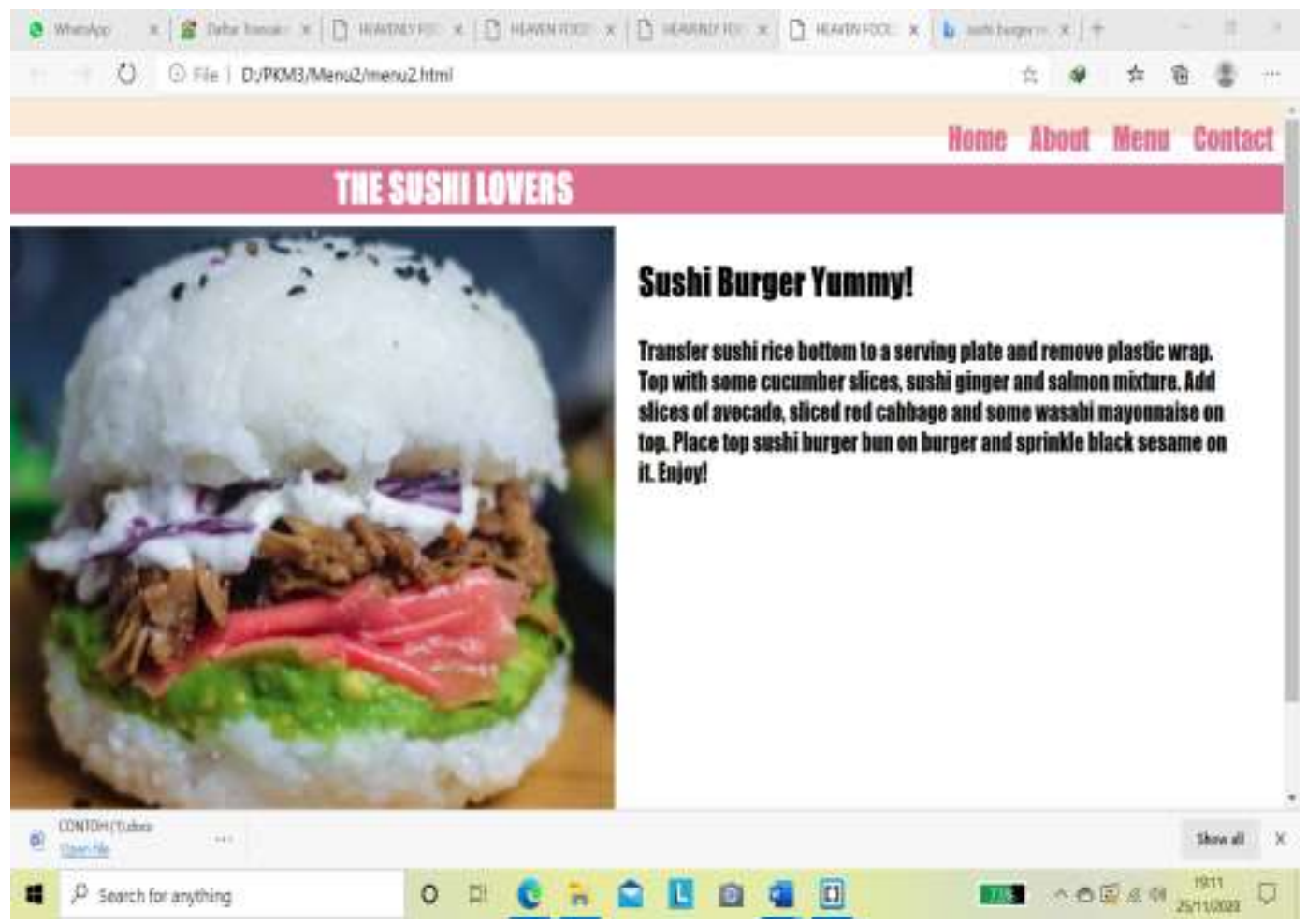

Gambar 2. Salah satu menu yang ditampilkan di websites 


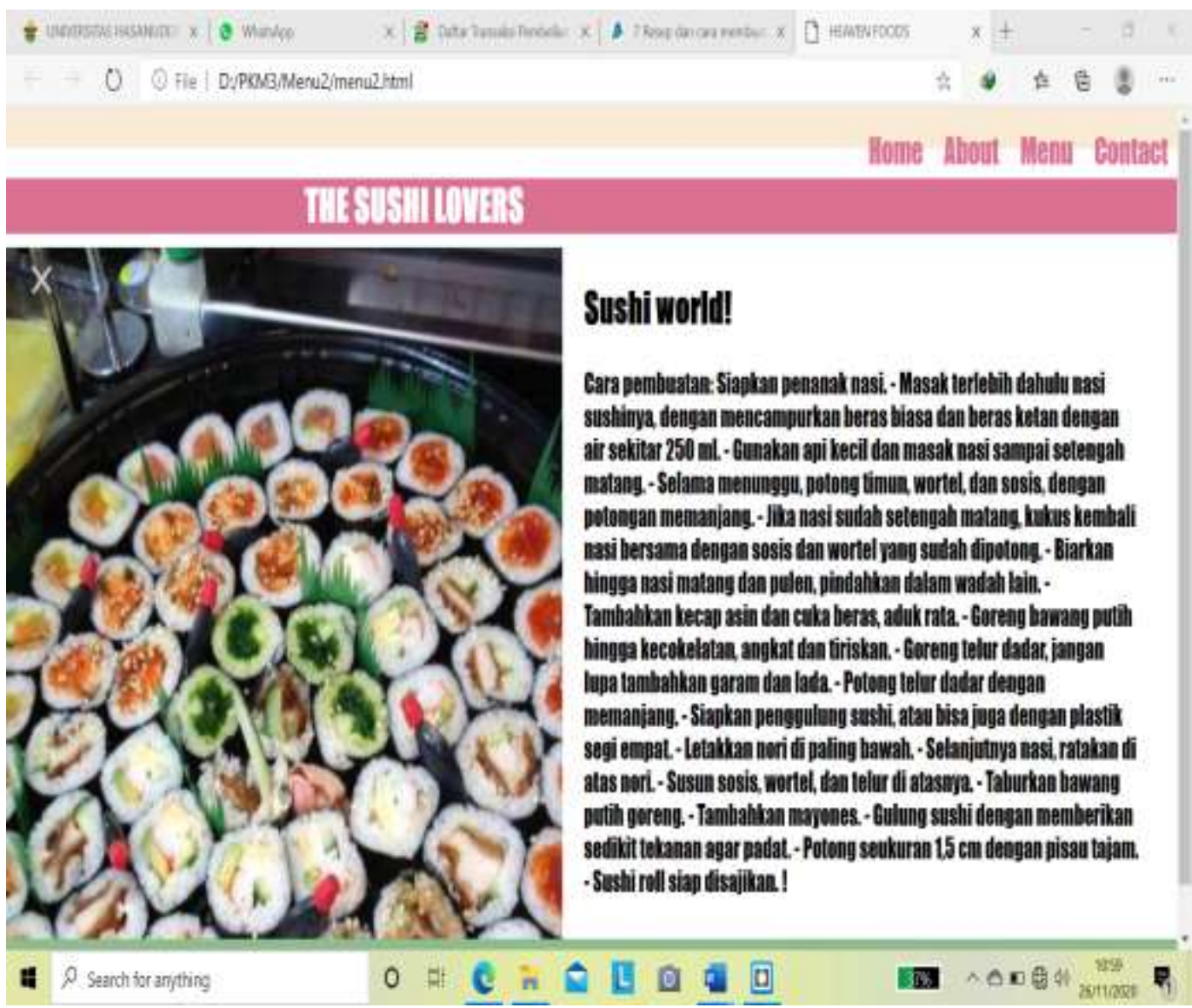

Gambar 3. Salah satu tampilan menu pada website

Website ini akan terus ditingkatkan agar UKM kecil ini mampu menangani keinginan konsumen melalui dari jarak jauh. Sehingga kedepannya, pandemic takkan menghalangi lagi UKM UKM kecil seperti ini untuk berkembang.

\section{KESIMPULAN}

Pemanfaatan website bisnis untuk sebuah UKM kecil sangatlah besar manfaatnya. Adanya pengalaman di masa pandemi corona, dimana UKM kecil tidak mampu berkembang, membuat program pengabdian ini bertujuan untuk mendesain sebuah website bisnis untuk UKM. UKM Pratama merupakan salah satu contoh mitra yang bersedia ditangani dengan memanfaatkan website bisnis ini. Hasilnya, UKM Pratama telah berkembang dikota makassar, dari sebuah UKM rintisan ibu rumah tangga menjadi catering yang mampu menyediakan panganan untuk ratusan karyawan pabrik dan instansi pemerintah setiap harinya. 
INTEGRITAS : Jurnal Pengabdian

Vol 5 No 1 Juli 2021

ISSN $2580-7978$ (cetak) ISSN 2615-0794 (online)

\section{UCAPAN TERIMA KASIH}

Ucapan terimakasih diberikan sebesar besarnya untuk mitra pengabdian ibu Andi Eka Wulansari, yang telah bersedia menjadikan UKM nya sebagai sarana percontohan dalam pemanfaatan website bisnis dalam mengembangkan UKM UKM kecil di Makassar.

Ucapan terima kasih juga diberikan pada masyarakat Makassar yang telah mendukung perkembangan UKM Pratama hingga sekarang.

\section{DAFTAR PUSTAKA}

Faithe Wempen, (2011), HTML 5 Step by Step, O'Reilly Media, Inc

Karnanda P. (2013). Bisnis Online Pemula. Tersedia pada: www.BisnisOnlinePemula.com

Neoelearning. (2014). Mengenal Bisnis Online lebih Dekat. Tersedia pada: www.NeoelearningClass.com

Terry Mc.Navage, (2010), Javascript for absolute beginner, Appress

Tiffany B.Brown, (2015), CSS Master, SidePoint.Pty,Ltd

Tim Hall and JP.Stacey, (2009), Phyton 3 for Absolute Beginner, Appress 